\title{
Tomato seed image analysis during the maturation ${ }^{1}$
}

\author{
Shara Regina dos Santos Borges ${ }^{2}$, Patricia Pereira da Silva ${ }^{3}$, Fernando Santos Araújo ${ }^{4}$, \\ Flívia Fernandes de Jesus Souza ${ }^{2}$, Warley Marcos Nascimento ${ }^{3 *}$
}

\begin{abstract}
The seed physiological potential has been directly related to normal formation process under morphological, structural and functional point of view. The objective of this study was to evaluate the internal morphology of 'BRS Nagai' tomato hybrid seeds at different stages of development and maturation, through the X-ray image analysis and relate the results with the seed germination and vigor. Seeds were extracted from fruits harvested at 30, 40, 50, 60 and 70 days after pollination (DAP). Subsequently, seeds were $\mathrm{x}$-rayed with their images analyzed visually for the embryo morphology classification; also, the measurement of clearance between the embryo and endosperm was performed with the help of the ImageJ software. These results were compared with the seed physiological quality by germination. The correlations involving the analysis of X-ray showed that the seeds have embryos classified as normal tend to have higher vigor and produce normal seedlings. On the other hand, seeds with higher internal free area tend to have low vigor and higher percentage of abnormal seedlings. The image analysis using X-rays is efficient for the study of physiological maturity of tomato seeds. The analysis of X-rays may predict seed performance by means of the embryo morphology, permitting the selection of high quality seeds. Tomato seeds of fruits with up to 40 days after pollination have low morphophysiological quality when compared to seeds extracted from fully mature fruits, from 60 days after pollination.
\end{abstract}

Index terms: Solanum lycopersicum L., seed morphology, X-rays.

\section{Análise de imagens na avaliação de sementes de tomate durante a maturação}

\begin{abstract}
RESUMO - O potencial fisiológico das sementes está diretamente relacionado à normalidade do processo de formação delas, sob ponto de vista morfológico, estrutural e funcional. Deste modo, o objetivo deste trabalho foi avaliar a morfologia interna de sementes de tomate, híbrido BRS Nagai, em diferentes estádios de maturação, por meio da análise de imagens de raios-X, relacionando com a germinação e o vigor das sementes. As sementes foram radiografadas tendo sido suas imagens analisadas para a classificação da morfologia do embrião e mensuração do espaço livre entre o embrião e endosperma, com auxílio do programa de análise de imagens ImageJ. Estes resultados foram comparados com a qualidade fisiológica através do teste de germinação. As correlações mostraram que as sementes possuidoras de embriões classificados como normais tendem a apresentar maior germinação, e produzir plântulas normais. E àquelas que possuem maior área livre interna tendem a apresentar ausência de germinação ou originarem maiores percentuais de plântulas anormais. A análise de imagens utilizando raios-X é eficiente para o estudo da maturidade fisiológica de sementes de tomate. A análise de raios-X pode predizer o desempenho das sementes por meio da morfologia do embrião, permitindo a seleção de sementes de alta qualidade. Sementes de tomateiro de frutos com até 40 dias após a polinização apresentam baixa qualidade morfofisiológica quando comparadas com sementes extraídas de frutos totalmente maduros, a partir dos 60 dias após a polinização.
\end{abstract}

Termos para indexação: Solanum lycopersicum L., morfologia da semente, raios X.

\section{Introduction}

The BRS Nagai is a tomato hydrid that presents wide

${ }^{1}$ Submitted on 02/21/2018. Accepted for publication on 10/17/2018. ${ }^{2}$ Programa de Pós-Graduação em Agronomia - PPGA-FAV, Universidade de Brasília, 70.910-900 - Brasília, Distrito Federal, Brasil.

${ }^{3}$ Embrapa Hortaliças, Caixa Postal 218, 70275-970 - Brasília, Distrito Federal, Brasil. tolerance to the main diseases that cause economic damages to the culture in Brazil. As the main transfer vector of this technology is the seed, resolution of problems related to seed

${ }^{4}$ Programa de Pós-Graduação em Agronomia - PPGA-CCA, Universidade Federal da Paraíba, Caixa Postal 66, 58397-000 - Areia, Paraíba, Brasil. *Corresponding author < warley.nascimento@embrapa.br> 
production needs to be prioritized.

For the tomato, the non-uniform maturation of the fruits is among the main problems in the production stage. Although the practice of split harvesting is the solution in this case, there is still a lack of information about when the fruits are apt to be harvested, that is, when the seeds reach physiological maturity.

The physiological maturity of tomato seeds has been identified based on fruit staining and physiological analyzes such as germination, vigor, moisture content and accumulation of dry matter (Valdes and Gray, 1998; Dias et al., 2006). Although these analyzes may provide sufficient information to determine the physiological maturity of the seeds, the evaluation of the physiological and physical components that influence seed quality during maturation can also be analyzed by other methodologies, such as radiographic image.

With this technique, besides other characteristics, it is possible to analyze the internal morphology of the seed in a fast and non-destructive way (Gomes et al., 2014). As seeds harvested at different maturation stages may present differences in internal structure, such as embryo anomalies, which are directly associated with germination and vigor (Silva et al., 2013b).

$\mathrm{X}$-ray image analysis can be quite useful specially when associated at softwares what allow a quantitative evaluation of morphological characteristics as an internal free area of the seed (Marcos-Filho et al., 2010), which also demonstrate a strong relation with the germination and vigor of seeds of vegetables such as bell peppers (Gagliardi and Marcos-Filho, 2011) and Physalis peruviana L. (Fernandes et al., 2016).

Thus, the objective of this study was to evaluate the internal morphology of BRS Nagai tomato seeds, at different stages of maturation, by X-ray image analysis, related with germination and seed vigor.

\section{Material and Methods}

\section{Plant material and crosses}

'BRS Nagai' tomato hybrid seeds were produced at Embrapa Hortaliças, Brasília, DF, Brazil, from February to May 2016. The parental lines were grown in pots kept in a protected environment following the usual recommendations for fresh tomatoes. Buds of female parent plants were hand emasculated before flower opening and mature pollen from male parent plants was collected by means of a vibrator. Pollination was performed daily being properly identified with labels containing the crossing date.

\section{Fruit harvest and seed extraction}

At 30, 40, 50, 60 and 70 days after pollination (DAP) approximately 60 fruits were harvested and the seeds extracted by hand and placed to fermentation process during $48 \mathrm{~h}$. After this period, seeds were washed in tap water, dried at room temperature for $24 \mathrm{~h}$ and then transferred to a ventilated chamber at $32{ }^{\circ} \mathrm{C}$ for $24 \mathrm{~h}$. After drying, seeds were placed in aluminum envelops and stored in cold $\left(7^{\circ} \mathrm{C}\right)$ chamber until use. Before and after drying the seeds were evaluated for moisture content by the drying method at $105 \pm 3{ }^{\circ} \mathrm{C}$ for $24 \mathrm{~h}$ with three $1.0 \mathrm{~g}$ seed samples for each season and the results were expressed as percentage (wet basis) and dry mass, determined in four replications of 50 seeds based on the final weight after drying in $\mathrm{mg}$. seed ${ }^{-1}$ (Brasil, 2009).

\section{Radiographic images}

The images were obtained in the Seed Analysis Laboratory at ESALQ/USP, Piracicaba, SP, Brazil. The X-ray test was performed with five replications of 20 seeds from each lot. Seeds were fixed on a tape in transparent plastic sheet and numbered according to the position occupied, so that could be identified in subsequent tests. The plastic foil was placed inside the digital X-ray equipment, trademark Faxitron ${ }^{\circledR}$, Model MX-20 DC-12 and subjected to radiation for 20 seconds to 20 $\mathrm{kV}$. Then the generated images were saved to disk computer for analysis. After the analysis of X-ray, seeds were submitted to germination test, respecting the order of X-ray images. The X-ray images were used for assessment of embryo morphology and presence of endosperm and assessing the free area within the seed. Embryos were classified as normal or abnormal (Figure 1), adapting the method described by Burg et al. (1994). An abnormal embryo had strongly bent, dented, broken or not fully formed. The normal embryo contained two cotyledons in perfect condition, presenting two basic configurations, generally found in tomatoes, which are coiled, where the cotyledons are laminated in the same direction and glasses, in which the cotyledons are in opposite directions.

\section{Germination test}

The radiographed seed were distributed over two sheets of blotting paper moistened with distilled water in the amount equivalent to 2.5 times the weight of dry paper, distributed in transparent plastic boxes $(11 \times 11 \times 3 \mathrm{~cm})$ and incubated at alternating temperature of $20-30{ }^{\circ} \mathrm{C}$. Readings were performed at 5 and 14 days, according to the Brazilian Rules for Seed Testing (RAS). Together the following variables were evaluated: speeds of germination - daily counts of the number of normal seedlings up to 14 days after sowing, and calculating 
as Maguire (1962); first count - accounting of normal seedlings on the fifth day after sowing (Brasil, 2009). On the fifth and fourteenth day after sowing it were recorded normal, abnormal seedlings and dead seeds (Brasil, 2009). During the countings, images of all seedlings were recorded using a digital camera (pixel) and saved on computer for later analysis.

\section{Analysis of free area}

Images of X-rayed seeds were saved in TIFF (Tagged Image File Format) format and analyzed using ImageJ software, adapting the methodology used by Silva et al. (2013a). The Image analysis was executed as follows: a) opening the image conversion to range type gray ( 8 bit); b) selection of area of interest for analysis - the analysis was performed of each seed individually delimiting each seed, so that the program analysed and soon after, there was a range selection that was used for calibration of the image; c) it was regarded as the pixel value in each image as a reference to $2368 \mathrm{X} 2340$ pixels and then, determined the area, perimeter and fraction seed area, which is the internal free areas; d) it was performed the color adjustment, for the separation of the areas of interest and other image constituents; e) the measurement was carried out with the above parameters and obtaining the results. These steps are summarized in Figure 1.
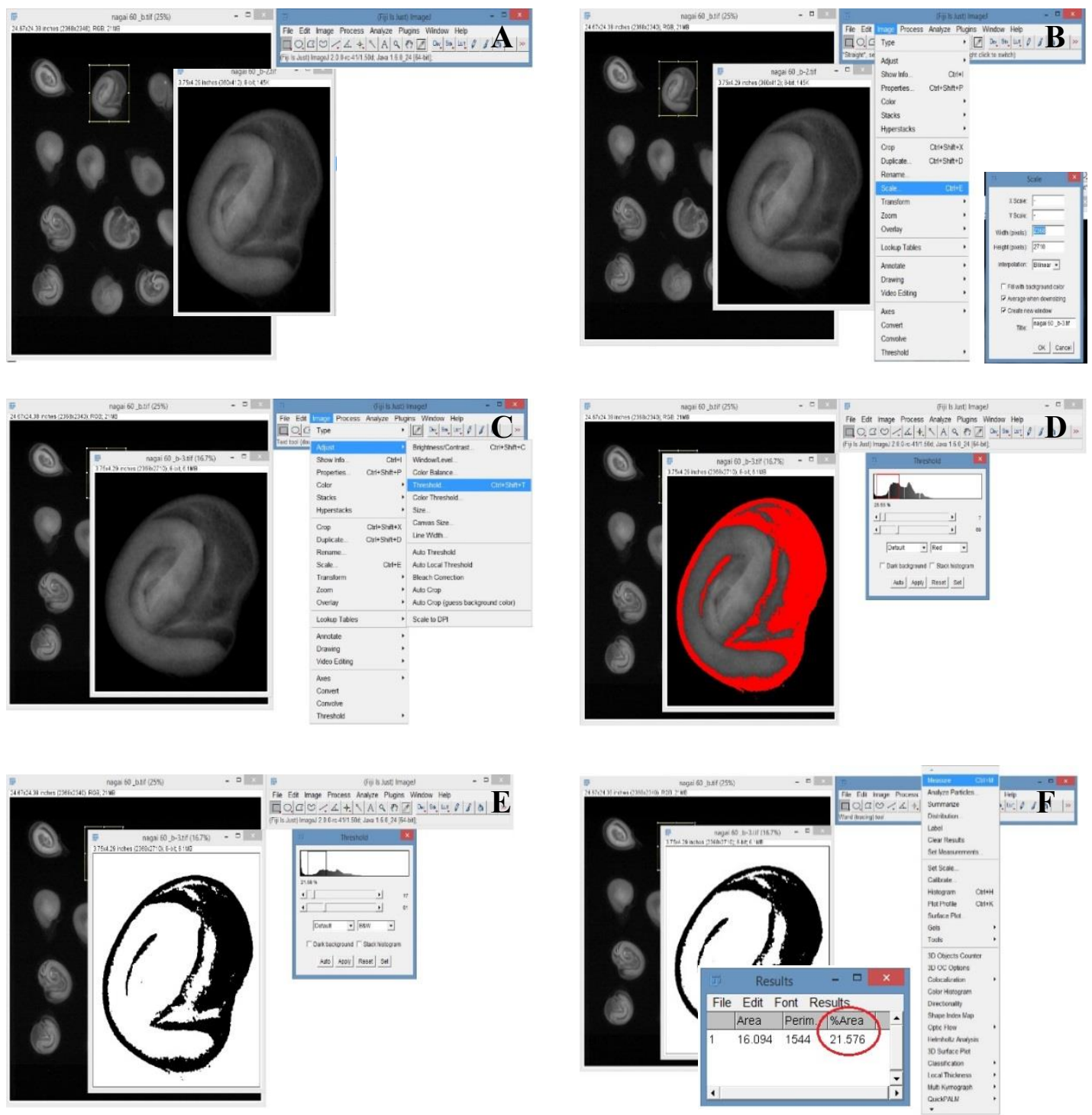

Figure 1. Example of analysis of images of tomato seeds in the ImageJ program, showing the steps of: Opening and selecting the image (A); choice of measuring range (B); adjust the color scale (C, D e E); measurement and obtaining the percentage of free area $(\mathrm{F})$.

Journal of Seed Science, v.41, n.1, p.022-031, 2019 


\section{Experimental design and statistical analysis}

The results were analyzed for normality of residue distribution and uniformity of variance and those that did not present normal distribution and homogeneities were transformed into arc sen $(\mathrm{x} / 100)^{\wedge 1 / 5}$. Subsequently, they were submitted to analysis of variance and in order to compare the results, the different stages of maturation $(30,40,50,60$ and $70)$ considered as five seed lots. The means were compared by Scott Knott's test at $5 \%$ probability using Sisvar ${ }^{\circledR}$ software (Ferreira, 2011). It was also calculated the Pearson correlation coefficients (r) among all the variables.

\section{Results and Discussion}

The images obtained in seeds derived from different treatments showing morphologically normal and abnormal embryos are presented in Figure 2. This X-ray images show the two basic cotyledon morphology configurations of tomato seeds. Image 2D and 2E represent the 'spectacles' configuration and image $2 \mathrm{~F}$ represent the 'coiled' embryo configuration.

The moisture content from seeds harvested at different stages of maturation, after drying, ranged from 5.7 to $6.0 \%$. This is very important factor, since differences between the seed moisture content may influence image quality (Gagliard and Marcos-Filho, 2011) and the homogeinity of moisture is essential for standardization and comparability of results (Marcos-Filho, 1999). According to Simak (1991), the lower the seed moisture content, the higher the optical density, which enables greater differentiation of the internal parts of the seeds as seen in the X-ray images.

In each harvest, the fruits were subjectively characterized, adapting the methodology of Dias et al. (2006) according to the external staining. Fruits harvested at 30 DAP were completely green, with consistent mucilage and immature seeds that were cut by the knife blade when the fruits were split transversely to the medium. At 40 DAP the fruits were completely green, but approximately $70 \%$ of them had their seeds physically well formed, not being cut by the knife blade, while the others resembled the previous classification. The fruits harvested at $50 \mathrm{DAP}$ were at the beginning of ripening, with transient staining from green to red. Fruits harvested at 60 had completely red pericarp and firm consistency. The fruits harvested at 70 DAP showed a more intense red color and some fruits with flaccid tissue.

Table 1 shows that the content dry matter deposition increased significantly from $30\left(1.6 \mathrm{mg}\right.$. seed $\left.{ }^{-1}\right)$ to 40 DAP (3.6 mg. seed ${ }^{-1}$ ), showing significant differences, from which no difference was presented. This can be inferred that, during this period, the phases related to histodifferentiation and morphogenesis were occurring, because they occur concomitant to the accumulation of dry matter (Bewley et al., 2013). According to the accumulation of dry matter, it is observed that changes in water content occurred inversely, with a decrease in the moisture content of the seeds, with the increase of days to harvest the fruits, reaching the minimum water content at 60 days after, showing a reduction in the moisture content of the seeds during the development, decreasing from $68 \%$ (30 DAP) to $43 \%$ (60 DAP).

These results are in agreement with Marcos-Filho (2015) that, in fleshy fruits, the maximum dry mass content is reached when the seed moisture content is approximately $40 \%$. However, these values are considered to be relatively high, a
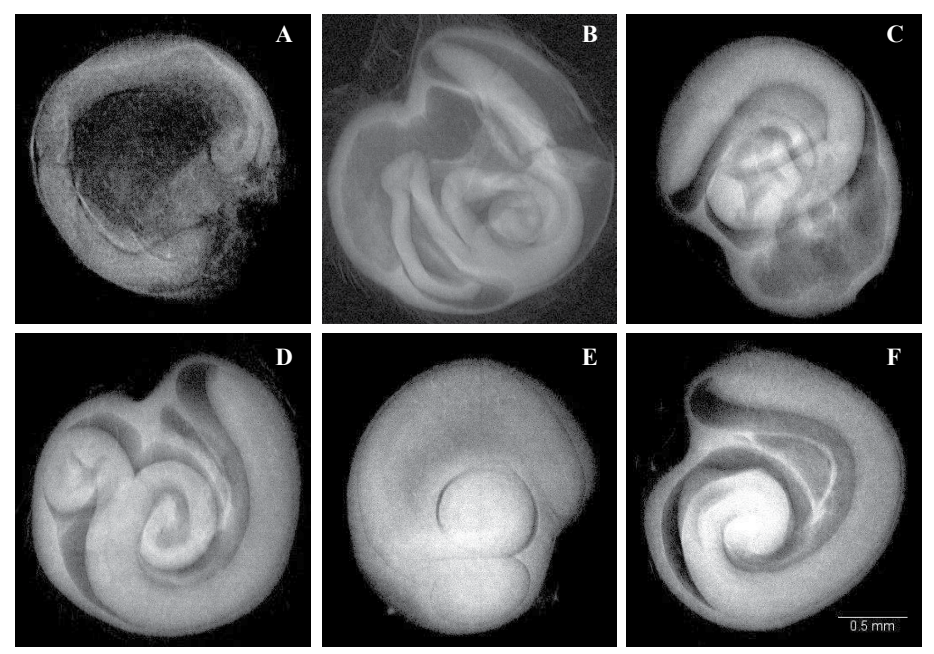

Figure 2. Radiographic images of 'BRS Nagai' tomato seed showing abnormal embryo (A, B and C), normal and configuration in glasses (D and E) and normal with configuration coiled (F). 
Table 1. Mean values of water content, dry matter, normal and abnormal seedlings, first count (\%), speeds of germination and seed dry weight in 'BRS Nagai' tomato seeds harvested at 30, 40, 50, 60 and 70 days after pollination (DAP).

\begin{tabular}{lrrrrrr}
\hline \multirow{2}{*}{ Variables } & \multicolumn{7}{c}{ DAP } & \multirow{2}{*}{ CV (\%) } \\
\cline { 2 - 5 } & \multicolumn{1}{c}{30} & \multicolumn{1}{c}{40} & \multicolumn{1}{c}{50} & 60 & 70 & \\
\hline Water content (\%) & $68.44 \mathrm{a}$ & $50.95 \mathrm{~b}$ & $47.74 \mathrm{c}$ & $43.14 \mathrm{e}$ & $45.48 \mathrm{~d}$ & 3.32 \\
Dry matter (mg.seed ${ }^{-1}$ ) & $1.60 \mathrm{~b}$ & $3.64 \mathrm{a}$ & $4.22 \mathrm{a}$ & $4.37 \mathrm{a}$ & $4.30 \mathrm{a}$ & 2.38 \\
Normal seedling (\%) & $0 \mathrm{~d}$ & $0 \mathrm{~d}$ & $30 \mathrm{c}$ & $52 \mathrm{~b}$ & $70 \mathrm{a}$ & 1.38 \\
Abnormal seedlings (\%) & $0 \mathrm{~b}$ & $5 \mathrm{~b}$ & $40 \mathrm{a}$ & $30 \mathrm{a}$ & $20 \mathrm{a}$ & 1.26 \\
Normal embryo (\%) & $0 \mathrm{~d}$ & $2 \mathrm{~d}$ & $36 \mathrm{c}$ & $56 \mathrm{~b}$ & $75 \mathrm{a}$ & 1.39 \\
Abnormal embryo (\%) & $100 \mathrm{a}$ & $98 \mathrm{a}$ & $64 \mathrm{~b}$ & $36 \mathrm{c}$ & $25 \mathrm{~d}$ & 0.30 \\
First counting (\%) & $0 \mathrm{c}$ & $0 \mathrm{c}$ & $19 \mathrm{~b}$ & $65 \mathrm{a}$ & $68 \mathrm{a}$ & 2.41 \\
Speed of germination & $0 \mathrm{c}$ & $0.1 \mathrm{c}$ & $1.1 \mathrm{~b}$ & $2.3 \mathrm{a}$ & $2.8 \mathrm{a}$ & 1.18 \\
\hline Free area (\%) & $49 \mathrm{a}$ & $35 \mathrm{a}$ & $24 \mathrm{~b}$ & $16 \mathrm{c}$ & $15 \mathrm{~d}$ & 1.13 \\
\hline
\end{tabular}

Means followed by the same letters between lines do not differ by Scott-Knott test at $5 \%$ probability.

fact also reported by several authors in works with species of fleshy fruits such as peppers (Demir and Ellis, 1992a), tomato (Demir and Ellis, 1992b; Valdes and Gray, 1998; Demir and Samit, 2001; Dias et al., 2006), eggplant (Demir et al., 2002) and finger pepper (Justino et al., 2015).

At germination was observed in seeds from fruit harvested at 30 and at 40 days after pollination, only $5 \%$ of seeds germinated although the seedling were abnormals (Table 1). In generally, fruits harvested in early stage of maturation show low seed germination. However, in many cases, particularly in those fleshy (tomato, pepper, melon etc.) fruits, the seed physiological maturity may be influenced by a period of fruit resting of post harvest before seed extraction (Silva et al., 2014). For instance, seeds from 'Kada' tomato fruits harvested at 40 DAP has no germination, but the same fruits storage for a period of 12 days promoted $98 \%$ of germination (Vidigal et al., 2006). Thus, it is suggested that the process of seed maturation may be completed with the temporary fruit storage.

It can be seen that seeds harvested at 30 DAP do not have germination capacity and are totally unfeasible, probably due to early interruption during the formation process, due to the fact that underdeveloped embryos do not tolerate desiccation (Bewley et al., 2013), since even the orthodox seeds have periods of sensitivity to drying during the formation, becoming unable to germinate (Barbedo et al., 2013; Marcos-Filho, 2015). Germination capacity begins at 40 DAP, although only seedlings considered abnormal.

Fruits harvested at 50 and 60 days after pollination had normal seedlings, however, the germination was lower than seeds from fruits harvested at 70 DAP (Table 1). Seeds from fruits harvested at 60 and 70 DAP also showed higher vigor in the first count and speed of germination. Similar results were obtained by Vidigal et al. (2006), which found that the maximum physiological quality of tomato seeds occurred on fruits harvested at $70 \mathrm{DAP}$; at this point, most of fruits showed $90 \%$ red color pericarp.

The Figure 3 shows the radiographic images of 'BRS Nagai' tomato seeds from fruits harvested at 50,60 and 70 DAP. Observe that the embryos are morphologically normal as well its respective normal seedlings. Demir and Samit (2001) found that seeds extracted from tomato fruits harvested at 70 DAP (with red and firm color), showed maximum physiological quality, which did not occur when the fruits were harvested at 50 DAP or at 80 DAP.

The highest percentages of normal embryos were obtained from seeds harvested at 60 and 70 DAP, as well as the lowest percentage of abnormal embryos and total free area. Most of the seeds that had higher percentage of free area showed abnormalities in the embryo, especially in the cotyledons: strongly folded, crumpled, broken or not fully formed. Seeds from fruits harvested at 30 and 40 DAP had mostly an abnormal embryo, and intense free area and therefore were not able to produce normal seedlings (Figure 4).

Eventually, even the seeds showing morphologically normal embryo, this has generated an abnormal seedling as shown in Figure 5. Burg et al. (1994) also verified that despite well-formed tomato seeds and without any apparent problem may give rise to abnormal seedlings or dead seeds, because the X-ray analysis may not detect certain physiological problems, such as, for example, intermediate steps of decay process, which could be affecting the germination process.

The results of the correlations between the variables are presented in Table 2 where it appears that most of the 

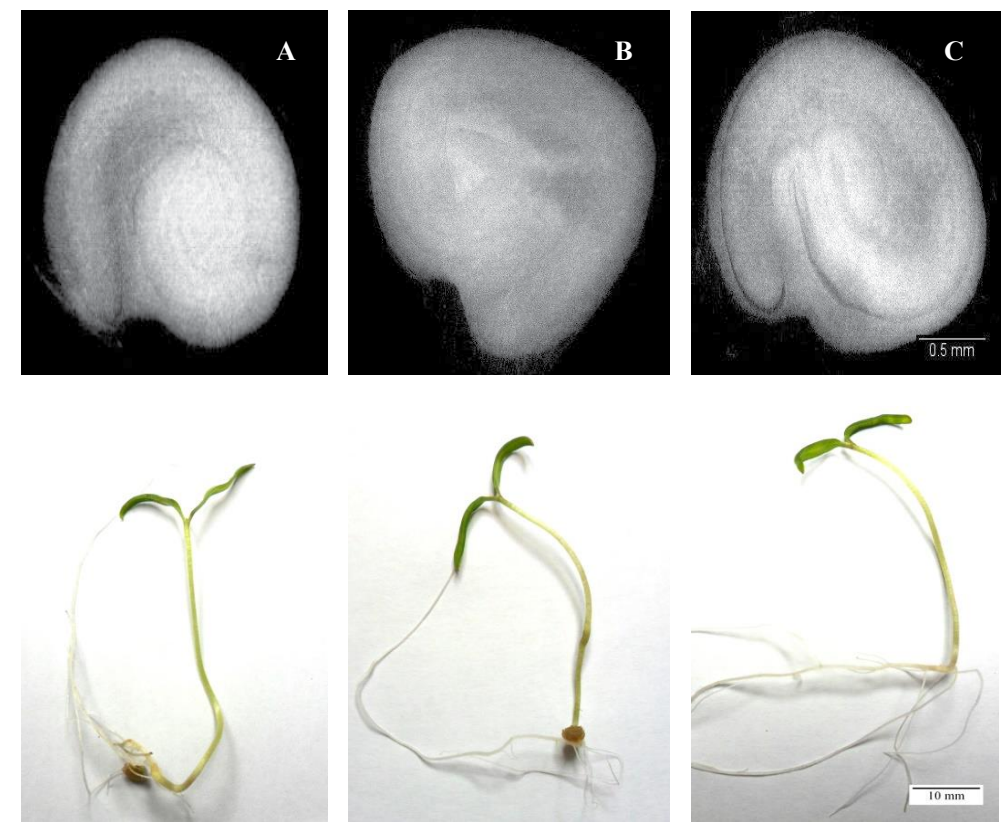

Figure 3. Radiographic images of 'BRS Nagai' tomato seeds from fruits harvested at 50 (A), 60 (B) and 70 (C) days after polination.
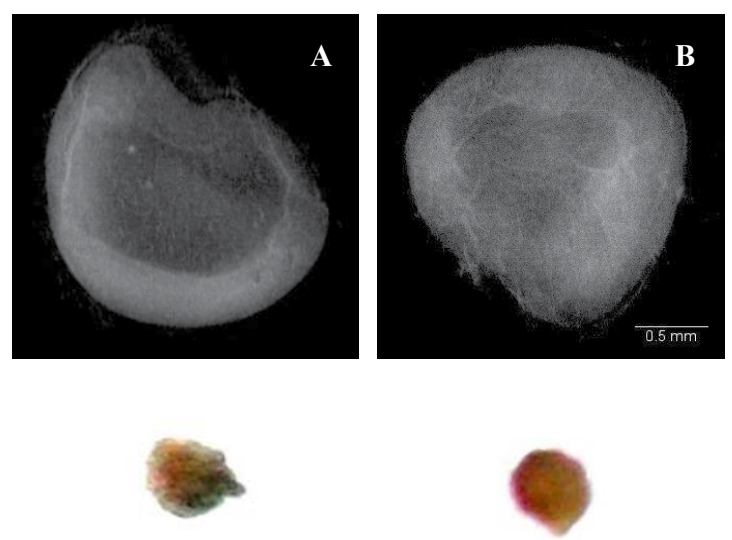

Figure 4. Radiographic images of tomato seeds 'BRS Nagai' tomato seeds from fruits harvested at 30 (A) and 40 (B) days after polination with extensive free area and abnormal embryo and their no germinated seeds.

coefficients obtained were high $(r>0.8)$ and significant. Correlations between image analysis of X-rays showed that the seeds have embryos classified as normal tend to have high speed of germination and first count, and produce normal seedlings, the opposite occurring when they have abnormal embryos. Also, those seeds that have higher internal free area tend to have lower accumulation of dry mass, the less vigor and produced higher percentage of abnormal seedlings.

The distribution of seeds as the free area within each treatment may be seen in the Figure 6. Note that the seeds from fruits harvested at 60 and 70 DAP had free area values below the general average, which was $28 \%$, while in the other periods the values of free areas was $60 \%$. Seeds harvested at 30 and 40 DAP showed higher free area porcentage justifying the absence of germination.

The average free area whose seeds produced normal seedlings was $20 \%$. This result may indicate that 'BRS Nagai' tomato hybrid seeds, with value higher than this free area, have immature and unable to germinate. This phenomenon may also be related to the lower amount of stored reserves, which are essential for the supply of energy for the initial germination processes, protein synthesis and respiration involved in the initial components stored during seed maturation (Nonogaki et al., 2010). In corn seed, Cícero and Banzatto Junior (2003) found that when the major transverse cracking damage was visible, the 

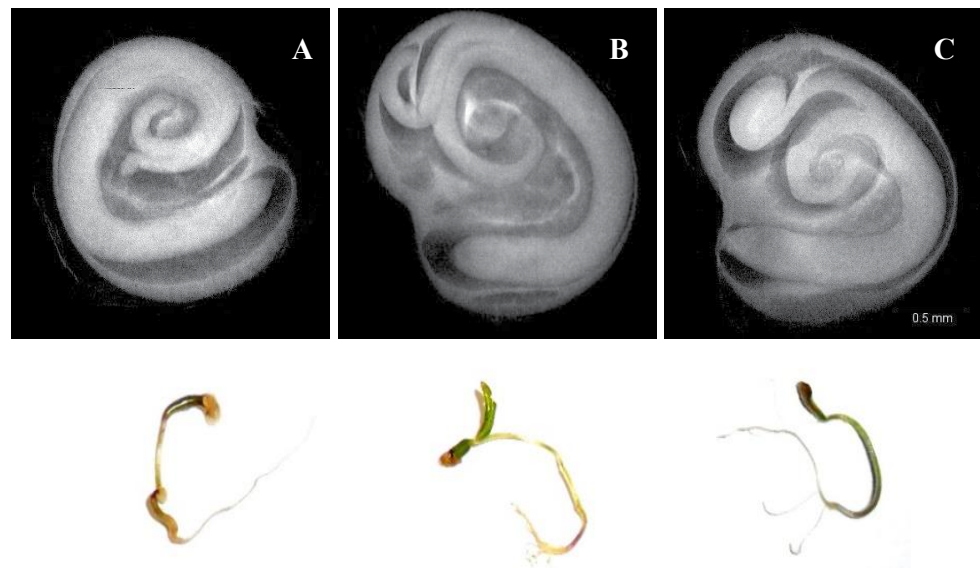

Figure 5. Radiographic images of 'BRS Nagai' tomato seeds from fruits harvested at 50 (A), 60 (B) and 70 (C) days after polination, with morphologically normal embryo and their abnormal seedlings.

Table 2. Pearson correlation coefficients ( $\mathrm{r}$ ) among the variables evaluated in 'BRS Nagai' tomato seeds from fruits harvested at 30, 40, 50, 60 and 70 days after pollination.

\begin{tabular}{lcccccccc}
\hline & $\mathrm{NS}$ & $\mathrm{AS}$ & $\mathrm{NG}$ & $\mathrm{NE}$ & $\mathrm{AE}$ & $\mathrm{SG}$ & $\mathrm{FC}$ & $\mathrm{DM}$ \\
\hline $\mathrm{AL}$ & $-0,88^{*}$ & $-0,67$ & $0,90^{* *}$ & $-0,89^{*}$ & $0,89^{* *}$ & $-0,87^{* *}$ & $-0,82^{* *}$ & $-0,92^{* *}$ \\
NS & & 0,53 & $-0,93^{* *}$ & $0,98^{*}$ & $-0,97^{*}$ & $0,97^{*}$ & $0,94^{*}$ & $0,72^{* *}$ \\
AS & & & $0,80^{* *}$ & $0,61^{*}$ & $-0,61^{*}$ & $0,57^{* *}$ & $0,48^{* *}$ & $0,66^{* *}$ \\
NG & & & & $-0,94^{* *}$ & $0,94^{* *}$ & $-0,92^{* *}$ & $-0,85^{* *}$ & $-0,80^{* *}$ \\
NE & & & & & $-1,00^{* *}$ & $0,98^{* *}$ & $0,94^{* *}$ & $0,74^{*}$ \\
AE & & & & & & $-0,98^{* *}$ & $-0,94^{* *}$ & $-0,73^{*}$ \\
SG & & & & & & & $0,98^{* *}$ & $0,72^{*}$ \\
FC & & & & & & & & $0,6^{* *}$ \\
\hline
\end{tabular}

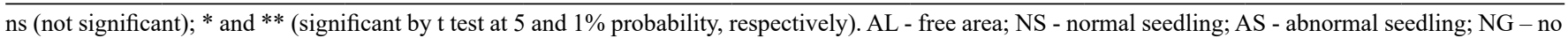
germinate seeds; NE - normal embryo; AE - abnormal embryo; SG - speed germination; FC - first count and DM - dry matter.

translocation endosperm nutrient for the embryo was impaired and therefore the number of abnormal seedlings increased. Menezes et al. (2012) mentioned that it is possible that the effect of damage to rice seed germination occurs due to the interruption in translocation of nutrients endosperm to the embryo.

Seeds with internal free areas also shown partially formed and were unable to produced normal seedlings as shown in Cecropia pachystachya Trec (Pupim et al., 2008) and Lithraea molleoides (Machado and Cicero, 2003). According to Gagliardi and Marcos-Filho (2011) the reduction of the area occupied by the internal cavity of the embryo and endosperm in pepper increased the percentage of abnormal seedlings and non-germinated seeds, indicating that this relationship may be used to estimate germination in some species.

Fernandes et al. (2016) verified that all lots of Physalis peruviana $\mathrm{L}$. presented a progressive increase in the percentage of normal seedlings when the free area was smaller, that is, when there was an increase of the area occupied by the endosperm. Similar results were also obtained with another solanacea, the eggplant, in the work of Silva et al. (2012) where seeds with higher area occupied by the endosperm and embryo presented better germination in ten seed lots tested.

For bell pepper, Dell'Aquila (2007) found that when the seeds had larger open areas than $2.7 \%$, relatively to its total area, in most cases, show abnormal seedlings. Amaral et al. (2011) using analysis of X-rays showed that most of the purple ipe seeds with damage to the embryonic axis and cotyledons produced abnormal seedlings and when the free area was higher than $50 \%$ of the total seed area, there was almost no germinated seeds.

Finally, the radiographic image analysis may be an alternative tool to study physiological maturity of tomato seeds by identifying internal seed features such as embryo morphology and presence of free areas, which may affect the physiological potential of seed lots. 

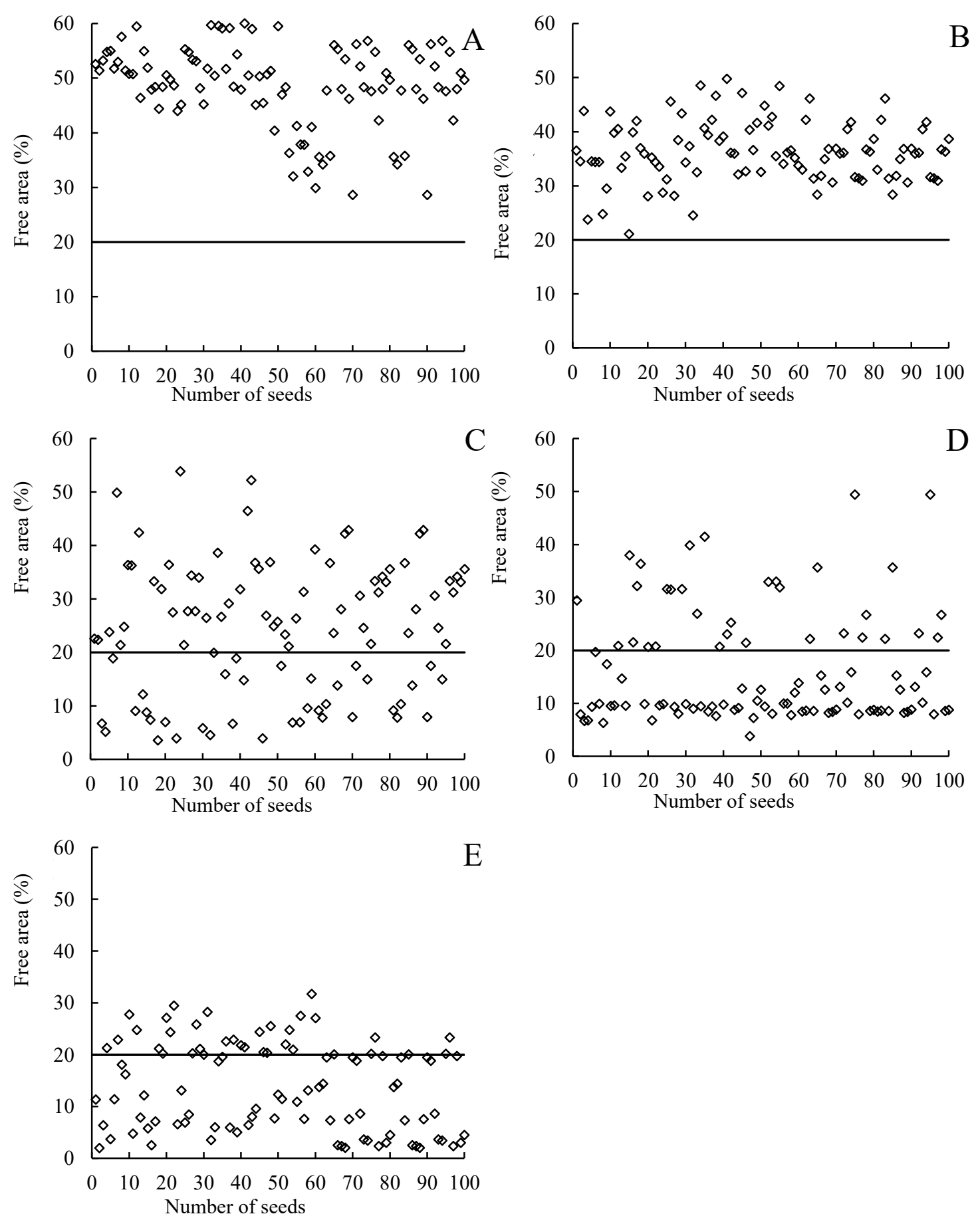

Figure 6. Distribution of free area within each 'BRS Nagai' tomato seeds from fruits harvested at 30 (A), 40 (B), 50 (C) 60 (D) and 70 (E) days after polination.

\section{Conclusions}

The image analysis using X-rays is efficient for the study of physiological maturity of tomato seeds. The analysis of $\mathrm{X}$-rays may predict seed performance by means of the embryo morphology, permitting the selection of high quality seeds. Tomato seeds of fruits with up to 40 days after pollination have low morphophysiological quality when compared to seeds extracted from fully mature fruits, from 60 days after pollination. 


\section{Acknowledgements}

The authors S.R.S.B and F.S.A thank CAPES (Coordenação de Aperfeiçoamento de Pessoal de Nivel Superior) for the scholarships.

\section{References}

AMARAL, J.B.; MARTINS, L.; FORTI, V.A.; CICERO, S.M.; MARCOS-FILHO, J. Teste de raios X para a avaliação do potencial fisiológico de sementes de ipê-roxo. Revista Brasileira de Sementes, v.33, n.4, p.601-607, 2011. http://www.scielo.br/scielo.php?script=sci_ arttext\&pid=S0101-31222011000400001\&lng=pt\&nrm=iso

BARBEDO, C.J.; CENTENO, D.C.; FIGUEIREDO-RIBEIRO, R.C.L. Do recalcitrant seeds really exist? Hoehnea, v.40, p.583-593, 2013. http://www.scielo.br/pdf/hoehnea/v40n4/01.pdf

BEWLEY, J.D.; BRADFORD, K.J.; HILROST, H.W.M.; NONOGAKI, H. Seeds: physiology of development, germination and dormancy. 3. ed., New York: Springer, 2013. 392p.

BRASIL. Ministério da Agricultura, Pecuária e Abastecimento. Regras para análise de sementes. Ministério da Agricultura, Pecuária e Abastecimento. Secretaria de Defesa Agropecuária. Brasília: MAPA/ACS, 2009. 395p.

BURG, W.J.; ARTESE, J.W.; ZOWL, R.A.; JALINK, H.; BINO, R.J. Predicting tomato seedling morphology by X-ray analysis of seeds. Journal of the American Society for Horticultural Science, v.119, n.2, p.258-263, 1994. http://journal.ashspublications.org/ content/119/2/258.full.pdf+html

CÍCERO, S.M.; BANZATTO JÚNIOR, H.L. Avaliação do relacionamento entre danos mecânicos e vigor, em sementes de milho, por meio da análise de imagens. Revista Brasileira de Sementes, v.25, n.1, p.25-28, 2003. http://www.scielo.br/scielo. php?script $=$ sci_arttext\&pid=S0101-31222003000100006\&lang=pt

DELL'AQUILA, A. Pepper seed germination assessed by combined X-radiography and computeraided imaging analyses. Biologia Plantarum, v.51, p.777-781, 2007. https://doi.org/10.1007/s10535007-0159-9

DEMIR, I.; ELLIS, R.H. Development of pepper (Capsicum annuum L.) seed quality. Annals of Applied Biology, v.121, p.385-399, 1992a.

DEMIR, I.; ELLIS, R.H. Changes in seed quality during seed development and maturation in tomato. Seed Science Research, v.2, p.81-87, 1992b. DOI https://doi.org/10.1017/S0960258500001173

DEMIR, I.; MAVI, K.; SERMENLI, T.; OZCOBAN, M. Seed development and maturation in aubergine (Solanum melongena). Gartenbauwissenschaft, v.67, p.148-154, 2002. https://www. researchgate.net/publication/285885838

DEMIR, I.; SAMIT, Y. Seed quality in relation to fruit maturation and seed dry weight during development in tomato. Seed Science and Technology, v.29, p.453-62, 2001.
DIAS, D.C.F.S.; RIBEIRO, F.P.; DIAS, L.A.S.; SILVA, D.J.H.; VIDIGAL, D.S. Maturação de sementes de tomate em função da ordem de frutificação na planta. Revista Ceres, v.53, n.308, p.446-456, 2006. http://www.ceres.ufv.br/ojs/index.php/ceres/article/view/3166/1061

FERNANDES, J.S.; SILVA, D.F.; SANTOS, H.O.; VON PINHO, E.V.R. Teste de raios $X$ na avaliação da qualidade de sementes de frutos de fisális em diferentes estádios de desenvolvimento. Revista de Ciências Agroveterinárias, v.15, n.2, p.165-168, 2016. http:// revistas.bvs-vet.org.br/rca/article/view/33044/36805

FERREIRA, D.F. Sisvar: A computer statistical analysis system. Ciência e Agrotecnologia, v.35, n. 6, p.1039-1042, 2011. http:// dx.doi.org/10.1590/S1413-70542011000600001

GAGLIARDI, B.; MARCOS-FILHO, J. Relationship between germination and bell pepper seed structure assessed by the X-ray test. Scientia Agricola, v.68, n.4, p.411-416, 2011 . http:// www.scielo.br/scielo.php?script=sci_arttext\&pid=S010390162011000400004\&lang=pt

GOMES, K.B.P.; MARTINS, R.C.C.; MARTINS, I.S.; GOMES JUNIOR, F.G. Avaliação da morfologia interna de sementes de Terminalia argentea (Combretaceae) pelo teste de raios X. Revista Ciência Agronômica, v.45, n.4, p.752-759, 2014. http://www. scielo.br/scielo.php?pid=S1806-66902014000400013\&script=sci_ abstract\&tlng=pt

JUSTINO, E.V.; BOITEUX, L.S.; FONSECA, M.E.N.; SILVA FILHO, J.G.; NASCIMENTO, W. M. Determinação da maturidade fisiológica de sementes de pimenta dedo de moça Capsicum baccatum var. pendulum. Horticultura Brasileira, v.33, n.3, p.324-331，2015. http://www.scielo.br/scielo.php?pid=S010205362015000300324\&script=sci_abstract\&tlng=pt

MACHADO, C.F.; CICERO, S.M. Aroeira-branca (Lithraea molleoides (Vell.) Engl. Anacardiaceae) seed quality evaluation by the X-ray test. Scientia Agricola, v.60, n.2, p.393-397, 2003.http://www.scielo.br/scielo. php?script=sci_arttext\&pid=S0103-90162003000200026\&lang=pt

MAGUIRE, J.D. Speeds of germination-aid selection and evaluation for seedlling emergence and vigor. Crop Science, v.2, p.176-177, 1962.

MARCOS-FILHO, J.; GOMES JUNIOR, F.G.; BENNETT, M.A.; WELLS, A.A.; STIEVE, S. Using Tomato Analyzer software to determine embryo size in x-rayed seeds. Revista Brasileira de Sementes, v.32, n.2, p.146-153, 2010. http://www.scielo.br/scieloOrg/ php/reference.php?pid=S0101-31222010000200018\&caller $=$ www. scielo.br\&lang=en

MARCOS-FILHO, J. Testes de vigor: importância e utilização. In: KRYZYZANOWSKI, F.C.; VIEIRA, R.D.; FRANÇA-NETO, J.B. (Ed.). Vigor de sementes: conceitos e testes. Londrina: ABRATES, p.1-24, 1999.

MARCOS-FILHO, J. Fisiologia de sementes de plantas cultivadas. 2 ed. Londrina: ABRATES, 2015. 660p.

MENEZES, N.L.; CICERO, S.M.; VILLELA, F.A.; BORTOLOTTO, R.P. Using X rays to evaluate fissures in rice seeds dried artificially. Revista Brasileira de Sementes, v.34, n.1, p.70-77, 2012. http:// www.scielo.br/scielo.php? script=sci_arttext\&pid=S01 01 31222012000100009\&lang $=\mathrm{pt}$ 
NONOGAKI, H.; BASSEL, G.W.; BEWLEY, J.D. GerminationStill a mystery. Plant Science, v.179, p.574-581, 2010. https://doi. org/10.1016/j.plantsci.2010.02.010

PUPIM, T.L.; NOVEMBRE, A.D.L.C.; CARVALHO, M.L.M.; CICERO, S.M. Adequação do teste de raios X para avaliação da qualidade de sementes de embaúba (Cecropia pachystachya). Revista Brasileira de Sementes, v.30, p.28-32, 2008. http:// www.scielo.br/scielo.php? script $=$ sci_arttext\&pid $=$ S 0101 $31222008000200004 \&$ lang $=$ pt

SILVA, P.P.; FREITAS, R.A.; CÍCERO, S.M.; MARCOS-FILHO, J; NASCIMENTO, W.M. Análise de imagens no estudo morfológico e fisiológico de sementes de abóbora. Horticultura Brasileira, v.32, n.2, p.210-214, 2014. http://www.scielo.br/scielo.php?script=sci_ arttext\&pid=S0102-05362014000200210\&lang=pt

SILVA, V.N.; CICERO, S.M.; BENNETT, M. Relationship between eggplant seed morphology and germination. Revista Brasileira de Sementes, v.34, n.4, p.597-604, 2012. http://www.scielo.br/scielo. php?script $=$ sci_arttext\&pid=S0101-31222012000400010

SILVA, V.N.; CICERO, S.M.; BENNETT, M. Associations between $\mathrm{X}$-ray visualised internal tomato seed morphology and germination. Seed Science and Technology, v.41, n.2, p.225-234, 2013a. https:// doi.org/10.15258/sst.2013.41.2.05
SILVA, V.N.; SARMENTO, M.B.; SILVEIRA, A.C.; SILVA, C.S.; CICERO, S.M. Avaliação da morfologia interna de sementes de Acca selowiana O. Berg. por meio de análise de imagens. Revista Brasileira de Fruticultura, v.35, n.4, p.1158-1169, 2013b. http://www. scielo.br/scielo.php?pid=S0100-29452013000400027\&script $=$ sci abstract\&tlng $=\mathrm{pt}$

SIMAK, M. Testing of forest tree and shrub seeds by X-radiography. In: GORDON, A.G.; GOSLING, P.; WANG, B.S.P. (Ed.) Tree and shrub seed handbook. Zurich: ISTA, 1991. p.1-28

VALDES, V.M.; GRAY, D. The influence of stage of fruit maturation on seed quality in tomato (Lycopersicon lycopersicum (L.) Karsten). Seed Science and Technology, v.26, n.2, p.309-318, 1998.

VIDIGAL, D.S.; DIAS, D.C.F.S.; NAVEIRA, D.S.P.C.; ROCHA, F.B.; BHERING, M.C.Qualidadefisiológica de sementes de tomate em função da idade e do armazenamento pós-colheita dos frutos. Revista Brasileira de Sementes, v.28, n.3, p.87-93, 2006. http://www.scielo. br/scielo.php?script $=$ sci_arttext\&pid=S0101-31222006000300013 